\title{
Relationships between soil properties and slope position in a lowland rain forest of southern Taiwan
}

\author{
Chun-Chih Tsui ${ }^{\mathrm{a}}$, Zueng-Sang Chen ${ }^{\mathrm{a}, *}$, Chang-Fu Hsieh ${ }^{\mathrm{b}}$ \\ ${ }^{a}$ Department of Agricultural Chemistry, National Taiwan University, Taipei 106-17, Taiwan \\ ${ }^{\mathrm{b}}$ Institute of Ecology and Revolutionary Biology, National Taiwan University, Taipei 106-17, Taiwan
}

Received 1 May 2003; received in revised form 24 November 2003; accepted 28 January 2004

Available online 8 March 2004

\begin{abstract}
The aspect and slope can control the movement of water and material in a hillslope and contribute to the spatial differences of soil properties. In a forest ecosystem, soil properties are also influenced by vegetation composition. The objectives of this study are to examine the characteristics and spatial differences of soil properties in a lowland evergreen broad-leaved rain forest in southern Taiwan, and to clarify the relationships between soil properties and the landscape. A total of 565 soil samples were taken at $0-5$ and $5-15 \mathrm{~cm}$ in 74 contiguous $10 \times 10-\mathrm{m}$ quadrates along an altitudinal transect ranging from 300 to $480 \mathrm{~m}$. The study transect was divided in three slope positions: summit, backslope and footslope positions, each with a different floristic composition and structure. Our study showed that organic carbon, available $\mathrm{N}$, available $\mathrm{K}$, extractable $\mathrm{Fe}$ and exchangeable $\mathrm{Na}$ were highest on the summit, while $\mathrm{pH}$, available $\mathrm{P}$, exchangeable $\mathrm{Ca}$ and $\mathrm{Mg}$ were significantly higher on the footslope at $0-5$ $\mathrm{cm}$ soils. Similar patterns were observed at subsurface $5-15-\mathrm{cm}$ depth soils. The OC increased with increasing altitude, probably due to the quality of litterfall and lower rate of decomposition in the summit forest. The results of redundancy analysis (RDA) also revealed clear separation of soil properties among slope positions. These results confirmed that slope factor involved in the transport and accumulation of solutes resulted in higher $\mathrm{pH}$, exchangeable $\mathrm{Ca}$ and $\mathrm{Mg}$, lower organic carbon, available $\mathrm{N}$ and $\mathrm{K}$, extractable $\mathrm{Zn}$ in the depositional areas of footslope. Although the soil properties associated with landscape have been better understood, further studies are required to clarify the relationships between soil nutrient status and plants in Taiwan.
\end{abstract}

(c) 2004 Elsevier B.V. All rights reserved.

Keywords: Soil properties; Vegetation; Altitudinal transect; Slope; Redundancy analysis

\section{Introduction}

The spatial variation of soil properties is significantly influenced by some environmental factors such as climate, topography, parent materials, vegetation, and disturbance due to human activity (Jenny, 1941; Chen et al., 1997; Chaplot et al., 2001; McKenzie and

* Corresponding author. Tel.: +886-2-2369-8349; fax: +886-2$2392-4335$.

E-mail address: soilchen@ccms.ntu.edu.tw (Z.-S. Chen).
Ryan, 1999; Ollinger et al., 2002). Some studies have indicated that soil properties are related to topographic positions in different forest ecosystems (Malo et al., 1974; Nizeyimana and Bicki, 1992; Stolt et al., 1993; Chen et al., 1997; De Bruin and Stein, 1998; King et al., 1999; Bohlen et al., 2001; Venterea et al., 2003). Soil moisture content is affected by the slope and aspect in the landscape (Franzmeier et al., 1969; Butler et al., 1986; Daniels et al., 1987). Temperature and precipitation varying with elevation have influence on the pedogenic processes as well. Forest soils 
are important sources of nutrients for vegetation, including $\mathrm{N}, \mathrm{P}, \mathrm{S}, \mathrm{K}, \mathrm{Na}, \mathrm{Ca}, \mathrm{Mg}$, and some micronutrients. In some cases, soil properties (for example, soil acidity and nutrient availability) also affect the vegetation types (Finzi et al., 1998a; Van Breemen et al., 1997; Van Breemen and Finzi, 1998), and the growth condition and distribution of vegetation types in different slope positions are controlled by the bioavailability of soil nutrients (Kubota et al., 1998). On the other hand, the nutrients in falling litter from different types of vegetation can return to the soils through microbial decomposition, soil mineralization, and nutrient recycling in the forest ecosystem. Such recycling processes also determine the spatial variation of soil nutrients in the forest (Finzi et al., 1998b).

The Nanjenshan Nature Reserve Site of Kenting National Park in southernmost Taiwan includes 2400 ha of subtropical and tropical lowland rain forests. This site was selected for a study of the effects of topographic position and vegetation type on soil properties because of its landscape diversity, varying vegetation patterns and free from human activities. Within the short range of $200-400 \mathrm{~m}$ in elevation, forest composes varieties of tropical, subtropical and temperate species, and the high biodiversity of vegetation indicates a phenomenon of vegetation compression (Liao, 1995). Few studies have been made of soil-vegetation and soil-landscape relationships along an elevation gradient in tropical or subtropical regions (Marrs et al., 1988; Grieve et al., 1990), and there has been no detailed investigation in Taiwan. The study reported here was conducted to characterize the distribution of soil chemical properties in a transect on Mt. Nanjenshan and to better understand the relationships between the soil properties and the variations of topographic position and vegetation.

\section{Materials and methods}

\subsection{Study area}

The study was carried out along a transect $\left(22^{\circ} 03^{\prime} 37 \mathrm{~N}, 120^{\circ} 51^{\prime} 10 \mathrm{E}\right)$ chosen in 1994 on the northwestern ridge of Mt. Nanjenshan (Liao, 1995). The transect is $450 \mathrm{~m}$ long and $40 \mathrm{~m}$ wide, and elevation ranges from $295 \mathrm{~m}$ at the valley site to 480 $\mathrm{m}$ on the summit of Mt. Nanjenshan. Slope angle varies between $17 \%$ and $89 \%$, and with a $70 \%$ average. The underlying bedrock within the study area consists primarily of sandstone and shale of Miocene age. Soils located on the summit with an argillic horizon are classified as Typic Paleudult resulted from strong leaching and illuvial processes. The soils located on the unstable backslope associated with steep slopes are classified as Typic Dystrudept resulted from weak leaching processes (Soil Survey Staff, 1999; Hseu et al., 2001). Two meteorological observatories were set at the altitude of 260 and $470 \mathrm{~m}$ to collect the data of rainfall, moisture, temperature, light, wind velocity and the wind direction (Lee, 1999). The collected data appeared no obvious differences in temperature and precipitation at these two elevations. Climatic data collected from October 1995 to March 2001 showed that the annual rainfall varied from 3250 to $3820 \mathrm{~mm}$ and was evenly distributed through the year. The mean annual air temperature was $22.7{ }^{\circ} \mathrm{C}$ and the mean monthly air temperature varied from $18.0{ }^{\circ} \mathrm{C}$ in January to $28.1{ }^{\circ} \mathrm{C}$ in July. It indicates that the study site has a hyperthermic soil temperature regime and an udic soil moisture regime (Soil Survey Staff, 1999).

A total of 139 free-standing woody species in 91 genera and 49 families was recorded along the transect (Liao, 1995). Owing to strong northeasterly monsoon winds in the winter, both forest structure and species composition change dramatically with exposure and elevation (Liao, 1994; Sun et al., 1998). Detrended correspondence analysis (DCA) of the vegetation data revealed three distinct forest types along the transect (see Appendix A) (Liao, 1995). Families found mainly in the tropics are dominant in the footslope forest. Conversely, families showing definite evidence of northern and eastern Asia affinities are better represented in the summit forest. Compared with those on the footslope and summit, the forest on the backslope represents a transition in structure, floristic composition and habitat. The litterfall patterns of three vegetation types are similar; production of total litterfall and wood litterfall on the footslope are higher than on the summit, but there is no difference in the leaf litter production among vegetation types (Chang, 1998). Chen (1998) reported that there was no clear difference in the decomposition rate of the widespread species along the altitudinal transect, but the nutrient flux on the footslope seems to be higher than on the summit. 


\subsection{Soil sampling}

Soil sampling was performed from February to August 1999. The transect was divided into 74 $10 \times 10-\mathrm{m}$ quadrates using transits, taps, and staid rods. A topographic map was constructed from aspect and slope data measured at corners of each quadrate. Within each quadrate, vegetation species were identified and the diameter at breast height (dbh) was measured for all woody stems having a dbh $\geq 1 \mathrm{~cm}$. The species were named according to the Flora of Taiwan (Huang, 1993-2000).

Each $10 \times 10-\mathrm{m}$ quadrate was further divided into four $5 \times 5-\mathrm{m}$ subquadrates. Within each subquadrate, three soil samples were sampled by an auger with a diameter of $8 \mathrm{~cm}$, at two soil depths, $0-5 \mathrm{~cm}$ (layer 1) and 5-15 cm (layer 2). These samples were then mixed to obtain a representative bulk sample for each subquadrate. A total of 565 soil samples were collected from 74 quadrates. These samples were then air dried and passed through a 2-mm sieve.

\subsection{Chemical analysis}

The soil properties were obtained according to the methods of USDA-NRCS (Soil Survey Laboratory Staff, 1996). The $\mathrm{pH}$ measurements were made on soil-water and soil- $\mathrm{KCl}$ solution mixtures in a ratio of $1: 1$. Organic $\mathrm{C}$ was determined by the modified Walkley-Black method. Exchangeable K, Na, Ca and $\mathrm{Mg}$ were extracted using $1 \mathrm{M}$ ammonium acetate $(\mathrm{pH}$ 7.0). Available $\mathrm{Fe}, \mathrm{Mn}, \mathrm{Cu}$ and $\mathrm{Zn}$ were extracted using DTPA-TEA solution ( $\mathrm{pH}$ 5.3). The concentrations of $\mathrm{K}, \mathrm{Na}, \mathrm{Ca}, \mathrm{Mg}, \mathrm{Fe}, \mathrm{Mn}, \mathrm{Cu}$, and $\mathrm{Zn}$ were measured by atomic absorption spectroscopy (Hitachi, 180-30 type). The soil-available $\mathrm{N}$, after incubation at $40{ }^{\circ} \mathrm{C}$ for 7 days, was extracted using $4 \mathrm{M} \mathrm{KCl}$ and was then measured with a Kjwltec Autosampler System 1035 Analyzer. Available P and K were measured by the Bray No. 1 method and the Mehlich No. 1 method, respectively.

\subsection{Statistical analysis}

In order to obtain a display of the soil-landscape relationship, redundancy analysis (RDA, program CANOCO) (ter Braak, 1990) was applied to soil data with elevation, slope and vegetation type as external variables. A Monte Carlo permutation test was performed to determine the relative importance of each variable in explaining the soil variation. One-way analysis of variance was used to test whether there were significant differences in soil properties between different slope positions (SAS Institute, 1990).

\section{Results and discussion}

\subsection{Spatial differences of soil properties along the landscape}

There is no clear difference of climate along the study transect, however, floristic composition changes dramatically along this altitudinal gradient. Whether plant species distribution is controlled by the soil nutrient condition or not, detailed investigation of soil properties is helpful for further study subsequently.

Results for redundancy analysis of soil data in the $0-5$ - and 5-15-cm depths show clear separation of groups, illustrating distinct differences between soils of each study site (Fig. 2). The Monte Carlo test indicated that the soil variation was significantly related to each of the external variables supplied $(p<0.001)$. The first axis, can account for $70.6 \%$ and $80.9 \%$ of the total variance for each depth. The elevation (or slope position) is the major determinant of the first axis and also significantly correlated with vegetation. The second axis, expressing the remaining $17.9 \%$ and $14.4 \%$ of the total variance, is highly correlated with slope.

Significant differences among slope positions were observed for most soil properties. Soil $\mathrm{pH}$, available P, exchangeable $\mathrm{Ca}, \mathrm{K}$ and DTPA-extractable $\mathrm{Mn}$ usually increased in a downslope direction, while organic carbon, available $\mathrm{K}$, exchangeable $\mathrm{Na}$ and DTPAextractable Fe tended to decrease (Table 1). The concentration of exchangeable $\mathrm{Mg}$ was highest on the footslope position than elsewhere. Values of soil properties were generally lower at 5-15-depth as compared with those in the upper $5 \mathrm{~cm}$, however, similar trends were found for most soil properties among slope positions (Table 1).

Hseu et al. (2001) selected three representative soil pedons on the summit, backslope and footslope positions of the study site, to describe soil micromorphological characteristics and to interpret the pedogenic 
Table 1

Comparisons of soil properties at different landscape positions of the study site

\begin{tabular}{|c|c|c|c|c|c|c|c|c|c|c|}
\hline \multirow{2}{*}{$\begin{array}{l}\text { Landscape } \\
\text { position }\end{array}$} & \multirow{2}{*}{$\begin{array}{l}\text { Elevation } \\
(\mathrm{m})\end{array}$} & \multirow{2}{*}{$\begin{array}{l}\text { Sample } \\
\text { number }(n)\end{array}$} & \multirow[t]{2}{*}{$\mathrm{pH}_{\text {water }}$} & \multirow[t]{2}{*}{$\mathrm{pH}_{\mathrm{KCI}}$} & Available N & Mineralizable N & Available P & Available K & \multirow{2}{*}{\multicolumn{2}{|c|}{$\begin{array}{l}\mathrm{OC}^{\#} \\
(\mathrm{~g} / \mathrm{kg})\end{array}$}} \\
\hline & & & & & \multicolumn{4}{|l|}{$\mathrm{mg} / \mathrm{kg}$} & & \\
\hline \multicolumn{11}{|l|}{$0-5 \mathrm{~cm}$ soil } \\
\hline Summit & $470-480$ & 20 & $4.8 \mathrm{~b}^{+}$ & $3.4 \mathrm{c}$ & $152 \mathrm{a}$ & $127 \mathrm{a}$ & $10.7 \mathrm{~b}$ & $41.1 \mathrm{a}$ & $29.6 a$ & \\
\hline Upper backslope & $400-470$ & 13 & $4.9 \mathrm{~b}$ & $3.4 \mathrm{c}$ & $131 b$ & $126 a$ & $8.55 b$ & $38.0 \mathrm{ab}$ & $26.7 b$ & \\
\hline Lower backslope & $330-400$ & 27 & $5.0 \mathrm{~b}$ & $3.6 \mathrm{~b}$ & $123 b$ & $112 \mathrm{a}$ & $10.6 b$ & $30.9 \mathrm{c}$ & $22.5 \mathrm{c}$ & \\
\hline Footslope & $<330$ & 14 & $5.3 \mathrm{a}$ & $4.1 \mathrm{a}$ & $127 b$ & $123 a$ & $15.2 \mathrm{a}$ & $34.6 \mathrm{bc}$ & $14.9 \mathrm{~d}$ & \\
\hline \multicolumn{11}{|l|}{$5-15 \mathrm{~cm}$ soil } \\
\hline Summit & $470-480$ & 20 & $4.8 \mathrm{~b}$ & $3.3 \mathrm{c}$ & $99.9 \mathrm{a}$ & $83.5 \mathrm{a}$ & $9.68 b$ & $23.5 \mathrm{ab}$ & $24.0 \mathrm{a}$ & \\
\hline Upper backslope & $400-470$ & 13 & $4.7 b$ & $3.3 \mathrm{c}$ & $90.0 \mathrm{~b}$ & $71.3 \mathrm{a}$ & $7.03 \mathrm{c}$ & $25.2 \mathrm{a}$ & $21.5 b$ & \\
\hline Lower backslope & $330-400$ & 27 & $4.8 \mathrm{~b}$ & $3.5 \mathrm{~b}$ & $90.4 b$ & $79.8 \mathrm{a}$ & $8.92 \mathrm{bc}$ & $20.6 b$ & $19.0 \mathrm{c}$ & \\
\hline Footslope & $<330$ & 14 & $5.0 \mathrm{a}$ & $3.7 \mathrm{a}$ & $92.2 \mathrm{ab}$ & $85.5 \mathrm{a}$ & $12.1 \mathrm{a}$ & $20.4 b$ & $11.6 \mathrm{~d}$ & \\
\hline \multirow{2}{*}{$\begin{array}{l}\text { Landscape } \\
\text { position }\end{array}$} & \multirow{2}{*}{$\begin{array}{l}\text { Elevation } \\
(\mathrm{m})\end{array}$} & \multirow{2}{*}{$\begin{array}{l}\text { Sample } \\
\text { number }(n)\end{array}$} & \multicolumn{4}{|c|}{ Exchangeable bases $(\mathrm{mg} / \mathrm{kg})$} & \multicolumn{4}{|c|}{ DTPA extractable $(\mathrm{mg} / \mathrm{kg})$} \\
\hline & & & $\mathrm{Ca}$ & $\mathrm{Mg}$ & $\mathrm{K}$ & $\mathrm{Na}$ & $\mathrm{Fe}$ & $\mathrm{Mn}$ & $\mathrm{Zn}$ & $\mathrm{Cu}$ \\
\hline \multicolumn{11}{|l|}{$0-5 \mathrm{~cm}$ soil } \\
\hline Summit & $470-480$ & 20 & $20.1 b^{+}$ & $5.96 \mathrm{~b}$ & $17.4 \mathrm{a}$ & $4.34 \mathrm{a}$ & $28.6 \mathrm{a}$ & $4.51 \mathrm{c}$ & $0.31 \mathrm{a}$ & $\mathrm{ND}^{++}$ \\
\hline Upper backslpoe & $400-470$ & 13 & $18.1 \mathrm{~b}$ & $5.91 \mathrm{~b}$ & $15.8 \mathrm{ab}$ & $3.73 b$ & $21.6 \mathrm{a}$ & $4.17 \mathrm{c}$ & $0.22 b$ & ND \\
\hline Lower backslpoe & $330-400$ & 27 & $20.0 \mathrm{~b}$ & $5.88 \mathrm{~b}$ & $14.2 \mathrm{~b}$ & $2.69 \mathrm{c}$ & $23.4 \mathrm{~b}$ & $5.95 \mathrm{~b}$ & $0.27 \mathrm{a}$ & ND \\
\hline Footslope & $<330$ & 14 & $24.2 \mathrm{a}$ & $6.10 \mathrm{a}$ & $16.4 \mathrm{a}$ & $3.09 \mathrm{c}$ & $13.8 \mathrm{c}$ & $11.1 \mathrm{a}$ & $0.27 \mathrm{a}$ & ND \\
\hline \multicolumn{11}{|l|}{$5-15 \mathrm{~cm}$ soil } \\
\hline Summit & $470-480$ & 20 & $10.7 \mathrm{c}$ & $5.29 \mathrm{~b}$ & $9.69 \mathrm{ab}$ & $3.16 \mathrm{a}$ & $25.2 \mathrm{a}$ & $1.80 \mathrm{c}$ & $0.17 \mathrm{a}$ & ND \\
\hline Upper backslpoe & $400-470$ & 13 & $9.76 \mathrm{c}$ & $5.16 \mathrm{~b}$ & $9.31 b$ & $2.77 \mathrm{ab}$ & $20.8 b$ & $1.85 \mathrm{c}$ & $0.13 b$ & ND \\
\hline Lower backslope & $330-400$ & 27 & $14.1 \mathrm{~b}$ & $5.37 \mathrm{~b}$ & $9.96 \mathrm{ab}$ & $2.13 \mathrm{c}$ & $20.7 b$ & $4.32 \mathrm{~b}$ & $0.19 \mathrm{a}$ & ND \\
\hline Footslope & $<330$ & 14 & $19.4 \mathrm{a}$ & $5.81 \mathrm{a}$ & $10.8 \mathrm{a}$ & $2.37 \mathrm{bc}$ & $12.9 \mathrm{c}$ & $9.40 \mathrm{a}$ & $0.20 \mathrm{a}$ & ND \\
\hline
\end{tabular}

\# Organic carbon.

${ }^{+}$There is no significant difference with the same letter in a row at the $p=0.05$ level.

++ Not detectable.

processes. Soils at the summit are classified as Paleudult with deeper soil, stronger leaching and stronger clay illuviation than other soils. The soils of the backslope and footslope are classified as Dystrudept, with relatively weaker pedogenic and leaching processes and relatively greater surface erosion than on the summit position (Chen, 1998; Hseu et al., 2001).

Soil properties on different slope positions were significantly affected by the degree of soil development and the leaching processes. Soils on summit position contain less exchangeable $\mathrm{Ca}$ and $\mathrm{Mg}$, due to stronger leaching. Soils can significantly accumulate these soluble ions such as $\mathrm{Ca}, \mathrm{Mg}, \mathrm{K}$, and $\mathrm{Na}$ from the summit and deposit on the footslope position where leaching is weaker and soil enrichment is stronger $(p<0.05)$ (Table 3).

The distribution of exchangeable $\mathrm{Na}$ among slope positions was the reverse of exchangeable $\mathrm{Ca}$ and
Mg. It seems that proximity of the Pacific Ocean and strong northeasterly monsoon winds may have been responsible for the variation in $\mathrm{Na}$ concentrations across the study site. The canopy trees on the ridges may intercept air-borne $\mathrm{Na}$ which is then leached into the soils via throughfall and stemflow, resulting in the relatively higher $\mathrm{Na}$ concentration of the summit soil.

The amount of DTPA-extractable Mn on the footslope was also significantly higher than that on the summit and backslope $(p<0.05)$ (Table 1$)$. Mn is more easily reduced and is more soluble than $\mathrm{Fe}$ in the soil solution. Consequently, $\mathrm{Mn}$ is more mobile in this landscape system and accumulates on the lower footslope. The topography can affect the patterns of water flow within the soil system (Fig. 1b and c), and also strongly influences the movement and distribution of Mn (McDaniel et al., 1992). Soils on the footslope 
(a)

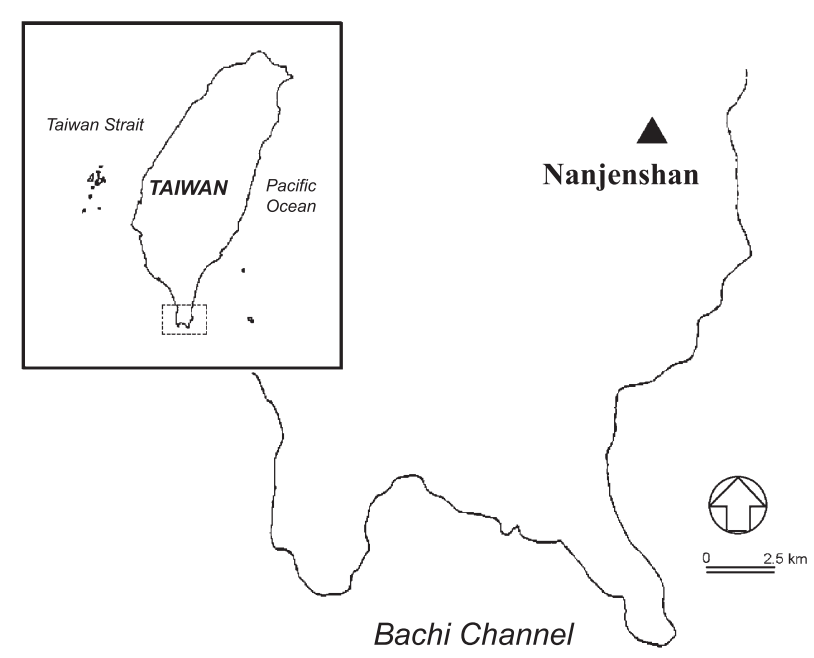

(b)
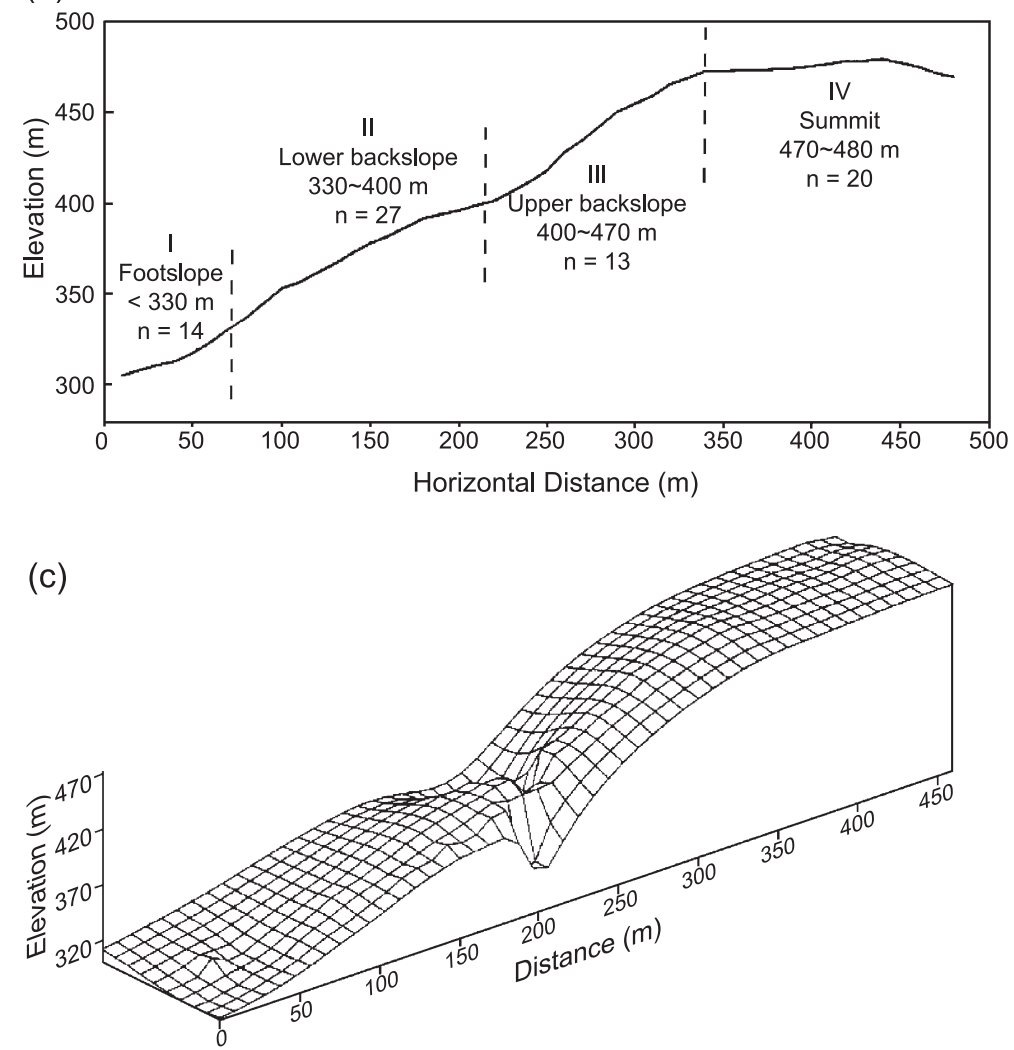

Fig. 1. (a) Geographical situation of Nanjenshan long-term ecological research site in Taiwan. (b) The Geomorphic profile of the study site (n: numbers of the $10 \times 10-\mathrm{m}$ sampling plots on slope positions with different elevations). (c) Topography of the study area. 
had a significantly higher $\mathrm{pH}$ than those on other slope positions due to the accumulation of soluble cations on the footslope $(p<0.05)$ (Table 1). The footslope can be regarded as a concave position in the landscape. Such a type of slope reduces the movement of soil water and accumulates some soluble cations from upper slope positions. These results agree with those of Huggett (1975).

Organic C content increased monotonically from $14.9 \mathrm{~g} / \mathrm{kg}$ on the footslope to $29.6 \mathrm{~g} / \mathrm{kg}$ on the summit (Table 1). Differences in the amount of organic $\mathrm{C}$ are probably due to the differences of litter decomposition rate. Previous studies (Liao, 1995; Chen, 1998; Lee, 1999) showed that the transition from footslope forest through backslope forest to summit forest is correlated with slightly decreasing decomposition quotients (lit- terfall content/litter layer), and markedly lower rates of decomposition as measured using litter bags. The lower rates of leaf litter decomposition in the summit forest may be a result of two important factors including the different leaf characteristics and lower temperature on the summit. The summit forest is mainly dominated by the species of Fagaceae, Lauraceae, Aqufoliaceae and Myrtaceae. Leaf structure data (Lin, 1998) indicated that significant differences between summit and footslope are smaller leaves with thicker outer epidermal wall and cuticle, and higher specific leaf weight, the characters that may reduce mineral leaching and are not favorable to decomposition (Sugden, 1985). Increased organic C on the summit relative to the linear slope could also result from deposition process. The gradient of the slope on

Table 2

Pearson correlation coefficients between soil properties in $0-5-\mathrm{cm}$ depth and slope

\begin{tabular}{|c|c|c|c|c|c|c|c|c|c|c|c|c|c|c|}
\hline & \multirow[t]{2}{*}{ Slope } & \multirow[t]{2}{*}{$\mathrm{pH}_{\text {water }}$} & \multirow[t]{2}{*}{$\mathrm{pH}_{\mathrm{KCl}}$} & \multicolumn{3}{|l|}{ Available } & \multirow[t]{2}{*}{$\mathrm{OC}$} & \multicolumn{4}{|c|}{ Exchangeable bases } & \multicolumn{3}{|c|}{ DTPA extractable } \\
\hline & & & & $\mathrm{N}$ & $\mathrm{P}$ & K & & $\mathrm{K}$ & $\mathrm{Na}$ & $\mathrm{Ca}$ & $\mathrm{Mg}$ & $\mathrm{Fe}$ & $\mathrm{Mn}$ & $\mathrm{Zn}$ \\
\hline Slope & 1.00 & & & & & & & & & & & & & \\
\hline $\mathrm{pH}_{\text {water }}$ & $0.33 * *$ & 1.00 & & & & & & & & & & & & \\
\hline $\mathrm{pH}_{\mathrm{KCl}}$ & $0.27 *$ & $0.89 * * *$ & 1.00 & & & & & & & & & & & \\
\hline $\begin{array}{c}\text { Avail. } \\
\text { N }\end{array}$ & $-0.44^{* * *}$ & 0.06 & 0.04 & 1.00 & & & & & & & & & & \\
\hline $\begin{array}{c}\text { Avail. } \\
\text { P }\end{array}$ & -0.22 & 0.16 & $0.35 * *$ & 0.09 & 1.00 & & & & & & & & & \\
\hline $\begin{array}{c}\text { Avail. } \\
\text { K }\end{array}$ & $-0.35^{* *}$ & 0.15 & 0.06 & $0.54 * * *$ & -0.06 & 1.00 & & & & & & & & \\
\hline O.C & $-0.40 * * *$ & $-0.48 * * *$ & $-0.59 * * *$ & $0.55 * * *$ & $-0.24 *$ & $0.40 * * *$ & 1.00 & & & & & & & \\
\hline $\begin{array}{c}\text { Exch. } \\
\text { K }\end{array}$ & $-0.26^{*}$ & $0.34^{* *}$ & $0.27 *$ & $0.60 * * *$ & 0.04 & $0.87 * * *$ & $0.25^{*}$ & 1.00 & & & & & & \\
\hline $\begin{array}{r}\text { Exch. } \\
\mathrm{Na}\end{array}$ & -0.13 & 0.17 & 0.03 & $0.47 * * *$ & -0.22 & $0.47 * * *$ & $0.42 * * *$ & $0.54 * * *$ & 1.00 & & & & & \\
\hline $\begin{array}{r}\text { Exch. } \\
\mathrm{Ca}\end{array}$ & -0.09 & $0.73 * * *$ & $0.75 * * *$ & $0.43 * * *$ & $0.31 * *$ & $0.33 * *$ & $-0.19 * *$ & $0.49 * * *$ & 0.18 & 1.00 & & & & \\
\hline $\begin{array}{r}\text { Exch. } \\
\mathrm{Mg}\end{array}$ & -0.02 & $0.73 * * *$ & $0.64 * * *$ & $0.49 * * *$ & 0.15 & $0.47 * * *$ & -0.09 & $0.63^{* * *}$ & $0.41 * * *$ & $0.85 * * *$ & 1.00 & & & \\
\hline $\begin{array}{c}\text { DTPA } \\
\text { extr. } \\
\text { Fe }\end{array}$ & $-0.31 * *$ & $0.63 * * *$ & $0.58 * * *$ & $0.61 * * *$ & 0.16 & $0.69 * * *$ & 0.07 & $0.86 * * *$ & $0.53 * * *$ & $0.85 * * *$ & $0.88 * * *$ & 1.00 & & \\
\hline $\begin{array}{c}\text { DTPA } \\
\text { extr. } \\
\text { Mn }\end{array}$ & 0.19 & $0.71 * * *$ & $0.68 * * *$ & $0.55^{* * *}$ & 0.21 & $0.51 * * *$ & -0.03 & $0.68 * * *$ & $0.46^{* * *}$ & $0.95 * * *$ & $0.90 * * *$ & $0.96 * * *$ & 1.00 & \\
\hline $\begin{array}{c}\text { DTPA } \\
\text { extr. } \\
\text { Zn }\end{array}$ & $-0.53 * * *$ & $0.72 * * *$ & $0.71 * * *$ & $0.51 * * *$ & $0.26^{*}$ & $0.47 * * *$ & -0.10 & $0.64 * * *$ & $0.33 * *$ & $0.98 * * *$ & $0.90 * * *$ & $0.94 * * *$ & $0.99 * * *$ & 1.00 \\
\hline
\end{tabular}




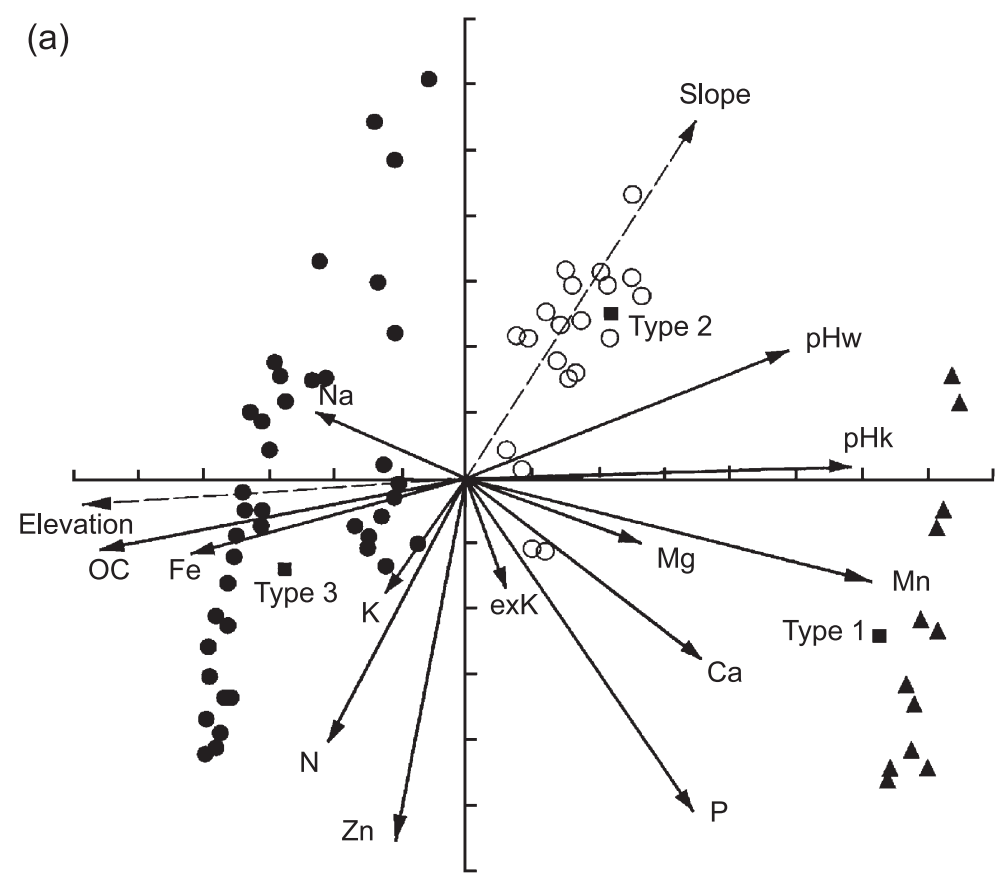

(b)

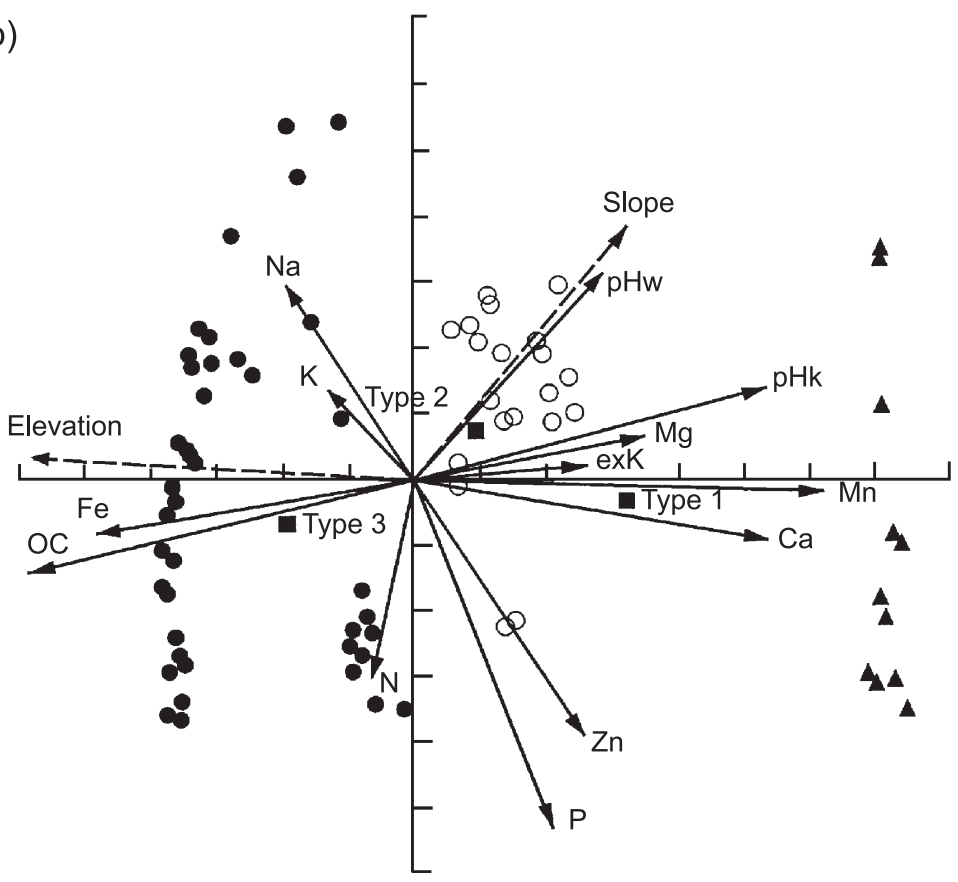

Fig. 2. Ordination diagram based on redundancy analysis of soil data in the $0-5 \mathrm{~cm}$ (a) and $5-15 \mathrm{~cm}$ (b) depths. Arrows represent the directions of maximum variation of soil and external variables. Soil samples designated by symbols representing the three slope positions ( $\boldsymbol{\Delta}$ footslope, $\bigcirc$ backslope, - summit, $\mathbf{a}$ centroids of vegetation types). $\mathrm{pHw}=\mathrm{pH}_{\text {water }} ; \mathrm{pHk}=\mathrm{pH}_{\mathrm{KCl}} ; \mathrm{N}, \mathrm{P}, \mathrm{K}=$ available $\mathrm{N}, \mathrm{P}$ and $\mathrm{K}$, respectively; OC=organic carbon; exK=exchangeable $\mathrm{K}$; $\mathrm{Na}, \mathrm{Ca}, \mathrm{Mg}=$ exchangeable $\mathrm{Na}, \mathrm{Ca}, \mathrm{Mg}$, respectively; Fe, Mn, Zn=DTPA-extractable Fe, Mn, Zn, respectively. 
the summit is moderate (Fig. 1b). This landscape minimizes soil erosion and may explain the higher organic $\mathrm{C}$ content on the forest floors of summit than the backslope, where the slope is steeper.

The available $\mathrm{N}$ and available $\mathrm{K}$ contents were highest in the summit soils as well as organic $\mathrm{C}$ (Table 1); however, there was less regular for the available $\mathrm{K}$ and no difference for the available $\mathrm{N}$ among other slope positions. In the case of available $\mathrm{P}$, the most marked difference is between the footslope site and all the others (Table 1). This variation remains unexplained and is possibly related with floristic composition. Here many tree-fall gaps occurred with abundant tropical pioneer species (Chan, 1994). There is evidence that soil in sites dominated by pioneer trees contains greater concentration of phosphorus than that obtained under the other types of vegetation studied (Kellman, 1969). Further studies on the distribution of nutrients in the above-ground materials and litterfall of major tree species are needed.

\subsection{Correlations among soil properties}

The correlation matrices for soils in the $0-5$ - and $5-15-\mathrm{cm}$ depths show several sets of significant relationships (Tables 2 and 3). The amount of organic carbon in the $5-15-\mathrm{cm}$ depth was negatively correlated with most selected soil properties, such as soil $\mathrm{pH}$, exchangeable $\mathrm{Ca}, \mathrm{Mg}$, and DTPA-extractable $\mathrm{Fe}$ and $\mathrm{Mn}$. In contrast, exchangeable $\mathrm{Na}$, available $\mathrm{N}$ and $\mathrm{K}$ were positively related to organic carbon. In the

Table 3

Pearson correlation coefficients between soil properties in 5-15-cm depth and slope

\begin{tabular}{|c|c|c|c|c|c|c|c|c|c|c|c|c|c|c|}
\hline & Slope & $\mathrm{pH}_{\text {water }}$ & $\mathrm{pH}_{\mathrm{KCl}}$ & Available & & & $\mathrm{OC}$ & Exchang & seable ba & ses & & DTPA ex & xtractable & \\
\hline & & & & $\mathrm{N}$ & $\mathrm{P}$ & $\mathrm{K}$ & & K & $\mathrm{Na}$ & $\mathrm{Ca}$ & $\mathrm{Mg}$ & $\mathrm{Fe}$ & $\mathrm{Mn}$ & $\mathrm{Zn}$ \\
\hline Slope & 1.00 & & & & & & & & & & & & & \\
\hline $\mathrm{pH}_{\text {water }}$ & 0.22 & 1.00 & & & & & & & & & & & & \\
\hline $\mathrm{pH}_{\mathrm{KCl}}$ & $0.32 * *$ & $0.78 * * *$ & 1.00 & & & & & & & & & & & \\
\hline $\begin{array}{c}\text { Avail. } \\
\text { N }\end{array}$ & $-0.32 * *$ & $0.31 * *$ & 0.15 & 1.00 & & & & & & & & & & \\
\hline $\begin{array}{c}\text { Avail. } \\
\text { P }\end{array}$ & $-0.31 * *$ & -0.02 & $0.13^{* *}$ & 0.18 & 1.00 & & & & & & & & & \\
\hline $\begin{array}{c}\text { Avail. } \\
\text { K }\end{array}$ & -0.08 & 0.20 & 0.005 & $0.31 * *$ & -0.04 & 1.00 & & & & & & & & \\
\hline O.C & $-0.36^{* *}$ & $-0.35 * *$ & $-0.60 * * *$ & $0.34 * *$ & -0.14 & $0.26^{*}$ & 1.00 & & & & & & & \\
\hline $\begin{array}{c}\text { Exch. } \\
\text { K }\end{array}$ & 0.14 & $0.44 * * *$ & $0.46 * * *$ & $0.39 * * *$ & -0.02 & $0.56 * * *$ & -0.12 & 1.00 & & & & & & \\
\hline $\begin{array}{r}\text { Exch. } \\
\mathrm{Na}\end{array}$ & -0.001 & $0.35 * *$ & 0.06 & $0.36^{* *}$ & $-0.23 *$ & $0.30 * *$ & $0.28 * *$ & $0.28 * *$ & 1.00 & & & & & \\
\hline $\begin{array}{r}\text { Exch. } \\
\mathrm{Ca}\end{array}$ & 0.18 & $0.70 * * *$ & $0.81 * * *$ & $0.30 * *$ & $0.24 *$ & -0.02 & $-0.59 * * *$ & $0.50 * * *$ & 0.003 & 1.00 & & & & \\
\hline $\begin{array}{r}\text { Exch. } \\
\mathrm{Mg}\end{array}$ & 0.14 & $0.73 * * *$ & $0.64 * * *$ & $0.32 * *$ & 0.02 & 0.13 & $-0.42 * * *$ & $0.55^{* * *}$ & $0.31 * *$ & $0.78 * * *$ & 1.00 & & & \\
\hline $\begin{array}{c}\text { DTPA } \\
\text { extr. } \\
\mathrm{Fe}\end{array}$ & $-0.32 * *$ & $0.74 * * *$ & $0.78 * * *$ & $0.40 * * *$ & 0.14 & 0.20 & $-0.46^{* * *}$ & $0.74 * * *$ & $0.25^{*}$ & $0.94 * * *$ & $0.85^{* * *}$ & 1.00 & & \\
\hline $\begin{array}{c}\text { DTPA } \\
\text { extr. } \\
\text { Mn }\end{array}$ & $0.29 *$ & $0.76^{* * *}$ & $0.80 * * *$ & $0.37 * *$ & 0.17 & 0.08 & $-0.51 * * *$ & $0.60 * * *$ & 0.21 & $0.97 * * *$ & $0.85^{* * *}$ & $0.98 * * *$ & 1.00 & \\
\hline $\begin{array}{c}\text { DTPA } \\
\text { extr. } \\
\text { Zn }\end{array}$ & -0.17 & $0.72 * * *$ & $0.71 * * *$ & $0.51 * * *$ & $0.26^{*}$ & $0.47 * * *$ & -0.10 & $0.58 * * *$ & 0.11 & $0.99 * * *$ & $0.83^{* * *}$ & $0.97 * * *$ & $0.99 * * *$ & 1.00 \\
\hline
\end{tabular}


upper 5-cm soil, however, no such significant relationships were found for exchangeable Mg and all DTPAextractable nutrients.

The highest positive correlations with soil $\mathrm{pH}$ in the upper $5 \mathrm{~cm}$ of soil were found, in descending order, for exchangeable $\mathrm{Ca}, \mathrm{Mg}$, and DTPA extractable $\mathrm{Zn}, \mathrm{Mn}$, $\mathrm{Fe}$ and exchanged $\mathrm{K}$, which were all intercorrelated. A similar result was observed at $5-15-\mathrm{cm}$ depth, although in different order. These findings follow the general principle that the concentration of basic cations should increase with increasing soil $\mathrm{pH}$ (Bohn et al., 1985). Available N and $\mathrm{K}$ are of course directly correlated with organic carbon, and therefore, their levels drop sharply below the upper $5 \mathrm{~cm}$ of organic enriched soil (Table 1). It thus appears that the amount of nutrients such as available $\mathrm{N}$ and $\mathrm{K}$ is associated with the accumulation of organic carbon which is in turn related to the quantity of litter falling on the forest floor.

\subsection{The effect of slope on soil properties}

Slope has been regarded as one of the most important abiotic factors that control the pedogenic process on a local scale (McDaniel et al., 1992; Buol et al., 1997). Steeper slopes contribute to greater runoff, as well as to greater translocation of surface materials downslope through surface erosion and movement of the soil mass (Hall, 1983). The study area was on a long, linear sideslope of Nanjenshan. While slope position has significant effect on the majority of soil properties, there were a number of soil properties which have also been found to be strongly correlated with the steepness of slope. In the redundancy analysis ordination diagrams, slope is the major determinant of axis 2 (Fig. 2a and b). The soil samples from both footslope and summit run roughly parallel to the slope arrow indicate a generality of soil response to slope for a given landscape. For surface soils of the upper $5 \mathrm{~cm}$, the highest negative correlations with slope were found, in descending order, for extractable $\mathrm{Zn}$, available $\mathrm{N}$, organic carbon, available $\mathrm{K}$, extractable $\mathrm{Fe}$ and exchangeable $\mathrm{K}$ (Table 2). The highest positive correlation was found for $\mathrm{pH}$. Similar trends are exhibited at a depth of 5-15 cm for organic carbon, available N, available $\mathrm{P}$, extractable $\mathrm{Fe}$, extractable $\mathrm{Mn}$, and $\mathrm{pH}$ (Table 3).

The influence of slope on soil properties has been related to concave and convex sloped surfaces that control the distribution of water and soluble materials from a higher to a lower elevation (Huggett, 1975; Pennock et al., 1987; Nizeyimana and Bicki, 1992). The accumulation of organic matter and soluble materials along the altitudinal transect could also be attributed to the pedogenic processes including tree throw, wind throw, and bioturbation that usually resulted in pits and mounds and created zone of litter and water accumulation. The role of these processes has been recognized by other studies (Schaetzl, 1990; Liechty et al., 1997; Johnson et al., 2000).

\section{Conclusions}

Slope and slope position significantly affected the movement and accumulation of soil solution, leading to a variation of soil properties along the transect in this study area. Significant differences among slope positions were found for most soil properties studied. The contents of available $\mathrm{P}$, exchangeable $\mathrm{Ca}$ and $\mathrm{Mg}$, DTPA-extractable $\mathrm{Mn}$, and $\mathrm{pH}$ value were highest on the footslope position. However, the contents of organic carbon, available $\mathrm{N}$ and $\mathrm{K}$, exchangeable $\mathrm{Na}$ and DTPA-extractable $\mathrm{Fe}$ were generally higher on the summit than those of backslope and footslope. As a result, redundancy analysis showed clear separation of soil groups, illustrating distinct differences between soils of each slope position. Differences in soil properties along the transect, including organic carbon, available $\mathrm{N}$ and extractable $\mathrm{Fe}$ that decreased from gentle slope to very steep slope, were also attributable to slope processes. Further studies on the distribution of nutrients in the above-ground materials and litterfall of major tree species are needed to more fully understand the interactive relationships among landscape, vegetation and soil properties.

\section{Acknowledgements}

The authors would like to thank the National Science Council of the Republic of China for financially supporting this research under Contract No. NSC-89-2621-B002-020. Mr. S. B. Wu, Ms. C. C. Wu and Ms. H. M. Chen are appreciated for their assistance in soil sampling and analyses. 


\section{Appendix A. Vegetation zones along the altitudinal gradient in the study site}

\begin{tabular}{|c|c|c|c|}
\hline Region & I & II, III & IV \\
\hline Elevation & $250-330 \mathrm{~m}$ & $330-470 \mathrm{~m}$ & $470-480 \mathrm{~m}$ \\
\hline $\begin{array}{l}\text { Plant } \\
\text { density }\end{array}$ & $1524 / \mathrm{ha}$ & 6660/ha & $8131 / \mathrm{ha}$ \\
\hline $\begin{array}{l}\text { Mean } \\
\text { base } \\
\text { area }\end{array}$ & $15.3 \mathrm{~m}^{2} / 1000$ plant & $7.58 \mathrm{~m}^{2} / 1000$ plant & $5.95 \mathrm{~m}^{2} / 1000$ plant \\
\hline $\begin{array}{c}\text { Number of } \\
\text { species }\end{array}$ & 71 & 72 & 100 \\
\hline \multirow{3}{*}{$\begin{array}{l}\text { Major } \\
\text { Genera }\end{array}$} & Moraceae & Lauraceae & Lauraceae \\
\hline & Rubiaceae & Euphorbiaceae & Fagaceae \\
\hline & Euphorbiaceae & Aquifoliaceae & Aquifoliaceae \\
\hline \multirow{11}{*}{$\begin{array}{l}\text { Major } \\
\text { Species }\end{array}$} & (1) White fig tree & (1) Leather-leaf holly & (1) Beautiful nerve eugenia \\
\hline & (Ficus benjamina) & (Ilex cochinchinensis) & (Syzygium euphlebium) \\
\hline & (2) Hengchun pencilwood & (2) Common schefflera & (2) Leather-leaf hollyc \\
\hline & (Dysoxylum kuskusense) & (Schefflera octophylla) & (Ilex cochinchinensis) \\
\hline & (3) Common schefflera & (3) Hieransan drypetes & (3) Narrow-leaved oak \\
\hline & (Schefflera octophylla) & (Drypetes hieranensis) & (Cyclobalanopsis longinux) \\
\hline & (4) Hieransan drypetes & (4) Three-leaved turpinia & (4) Red bark slugwood \\
\hline & (Drypetes hieranensis) & (Turpinia ternata) & (Beilschmiedia erythrophloia) \\
\hline & (5) Large-leaved nanmu & (5) Mountain longan & (5) Short-spine evergreen chinkapin \\
\hline & (Machilus japonica var. kusanoi) & (Helicia formosana) & (Castanopsis stellato-spina) \\
\hline & (6) Wild coffee (Psychotria rubra) & (6) Wild coffee (Psychotria rubra) & (6) Chinese aucuba (Aucuba chinensis) \\
\hline \multirow{8}{*}{$\begin{array}{l}\text { Special } \\
\text { species }\end{array}$} & (1) Poisonous wood nettle & Lienhuachih heliciamountain & (1) Hongkong oak \\
\hline & (Laportea pterostigma) & longan (Helicia rengetiensis) & (Cyclobalanopsis championii) \\
\hline & (2) White fig tree & & (2) Matsuda osmanthus \\
\hline & (Ficus benjamina) & & (Osmanthus marginatus) \\
\hline & (3) Autumn mapple & & (3) Kanehira holly \\
\hline & tree,red cedar (Bischofia janavica) & & (Ilex triflora var. kanehirai) \\
\hline & (4) Large-leaved aglaia & & (4) Chinese aucuba \\
\hline & (Aglaia elliptifolia) & & (Aucuba chinensis) \\
\hline
\end{tabular}

Liao, 1995.

\section{References}

Bohlen, P.J., Groffman, P.M., Driscoll, C.T., Fahey, T.J., Siccama, T.G., 2001. Plant-soil-microbial interactions in a northern hardwood forest. Ecology 82, 965-978.

Bohn, H.L., McNeal, B.L., O'Connor, G.A., 1985. Soil Chemistry, 2nd ed. Wiley, New York.

Buol, S.W., Hole, F.D., McCracken, R.J., Southard, R.J., 1997. Soil Genesis and Classification, 4th edition. Iowa State Univ. Press, Ames, IA.

Butler, J., Goetz, H., Richardson, J.L., 1986. Vegetation and soillandscape relationships in the north Dakota badlands. Am. Midl. Nat. 116, 378-386.

Chan, W.H., 1994. Studies on the gap-phase regeneration of the lowland rain forest in Nanjenshan Area. Master thesis, Graduate Institute of Botany, National Taiwan University Taiwan (In Chinese, with English abstract).

Chang, C.P., 1998. A research of litterfall in Nanjenshan lowland rain forest. Master thesis, Graduate Institute of Botany, Na- tional Taiwan University Taiwan (In Chinese, with English abstract).

Chaplot, V., Bernoux, M., Watler, C., Curmi, P., Herpin, U., 2001. Soil carbon storage prediction in temperate hydromorphic soils using a morphologic index and digital elevation model. Soil Sci. $166,48-60$.

Chen, Y.Y., 1988. Litter decomposition in a lowland rain forest of Nanjenshan. Master thesis, Graduate Institute of Botany, National Taiwan University Taipei (In Chinese with English Summary).

Chen, Z.S., Hsieh, C.F., Jiang, F.Y., Hsieh, T.H., Sun, I.F., 1997. Relationships of soil properties to topography and vegetation in a subtropical rain forest in southern Taiwan. Plant Ecol. 132, 229-241.

Daniels, W.L., Zelazny, L.W., Everett, C.J., 1987. Virgin hardwood forest soil of the southern Appalachian Mountains: II. Weathering, mineralogy, and chemical properties. Soil Sci. Soc. Am. J. $51,730-738$.

De Bruin, S., Stein, A., 1998. Soil-landscape modeling using fuzzy 
c-means clustering of attribute data derived from a digital elevation model (DEM). Geoderma 83, 17-33.

Finzi, A.C., Canham, C.D., van Breemen, N., 1998a. Canopy treesoil interactions within temperate forests: species effects on $\mathrm{pH}$ and cations. Ecol. Appl. 8, 447-454.

Finzi, A.C., van Breemen, N., Canham, C.D., 1998b. Canopy treesoil interactions within temperate forests: species effects on soil carbon and nitrogen. Ecol. Appl. 8, 440-446.

Franzmeier, D.P., Pederson, E.J., Longwell, T.J., Byrne, J.G., Losche, C.K., 1969. Properties of some soils of the Cumberland Plateau as related to slope aspect and position. Proc.-Soil Sci. Soc. Am. 33, 755-762.

Grieve, I.C., Proctor, J., Cousins, S.A., 1990. Soil variation with altitude on Volcan Barva Costa Rica. Catena 17, 525-534.

Hall, G.F., 1983. Pedology and geomorphology. In: Wilding, L.P., Smeck, N.E., Hall, G.F. (Eds.), Pedogenesis and Soil Taxonomy: I. Concepts and Interactions. Elsevier, Amsterdam, pp. $117-140$.

Hseu, Z.Y., Chen, Z.S., Tsai, C.C., Tsui, C.C., 2001. Using Micromorphology to interpret the genesis of tropical forest soils in the Nanjenshan area of Taiwan. Taiwan J. For. Sci. 16, 25-38 (In Chinese with English abstract).

Huang, T.C. (Ed.), 1993-2000. Flora of Taiwan, 2nd ed., vol. 2, pp. $1-855$; vol. 3 , pp. $1-1084$; vol. 4 , pp. $1-1217$, vols. $1-5$. Department of Botany. National Taiwan University, Taipei.

Huggett, R.J., 1975. Soil landscape systems: a model of soil genesis. Geoderma 13, 1-12.

Jenny, H., 1941. Factors of Soil Formation-A System of Quantitative Pedology McGraw-Hill, New York.

Johnson, C.E., Ruiz-Mendez, J.J., Lawrence, G.B., 2000. Forest soil chemistry and Terrain attributes in a Catskill watershed. Soil Sci. Soc. Am. J. 64, 1804-1814.

Kellman, M.C., 1969. Some environmental components of shifting cultivation in upland Mindanao. J. Trop. Geogr. 28, 40-56.

King, D., Bourennane, H., Isambert, M., Macaire, J.J., 1999. Relationship of the presence of a non-calcareous clay-loam horizon to DEM attributes in a gently sloping area. Geoderma 89, 95-111.

Kubota, D., Masunaga, T., Hermansah, Rasyidin, A., Hotta, M., Shinmura, Y., Wakatsuki, T., 1998. Soil environment and tree species diversity in tropical rain forest, West Sumatra, Indonesia. In: Schulte, A., Ruhiyat, D. (Eds.), Soil of Tropical Forest Ecosystems. Springer, Heidelberg, Germany, pp. 159-167.

Lee, S.J., 1999. Physiological and growth responses to different elevations and light environments in seedlings of six species of Nanjenshan forest. Master thesis, Graduate Institute of Tropical Agriculture, National Pingtung University Taiwan (In Chinese, with English abstract).

Liao, S.H., 1994. Relationships among soil chemical properties, topography and plant species in lower montane subtropical rain forest by redundancy analysis. Master thesis, Graduate Institute of Botany, National Taiwan University Taiwan (In Chinese, with English abstract).

Liao, C.C., 1995. Altitudinal variation in composition, structure, diversity and distribution pattern of the subtropical rain forest in Nanjenshan. Master thesis, Graduate Institute of Botany, National Taiwan University Taiwan (In Chinese, with English abstract).
Liechty, H.O., Jurgensen, M.F., Mroz, G.D., Gale, M.R., 1997. Pit and mound topography and its influence on storage of carbon, nitrogen, and organic matter within an old-growing forest. Can. J. For. Res. 27, $1992-1997$.

Lin, C.C., 1998. Leaf structure of Nanjenshan lowland rain forest trees. Master thesis, Graduate Institute of Botany, National Taiwan University Taiwan (In Chinese, with English abstract).

Malo, D.D., Worcester, B.K., Cassel, D.K., Matzdorf, K.D., 1974. Soil-landscape relationships in a closed drainage system. Proc. -Soil Sci. Soc. Am. 38, 813-818.

Marrs, R.H., Proctor, J., Heaney, A., Mountford, M.D., 1988. Changes in soils, nitrogen mineralization and nitrification along an altitudinal transect in tropical rain forest in Costa Rica. J. Ecol. 76, 466-482.

McDaniel, P.A., Bathke, G.R., Boul, S.W., Cassel, D.K., Falen, A.L., 1992. Secondary manganese/iron ratios as pedochemical indicators of field-scale throughflow water movement. Soil Sci. Soc. Am. J. 56, 1211-1217.

McKenzie, N.J., Ryan, P.J., 1999. Spatial prediction of soil properties using environmental correlation. Geoderma 89, 67-94.

Nizeyimana, E., Bicki, T.J., 1992. Soil and soil-landscape relationships in the north central region of Rwanda, east-central Africa. Soil Sci. 153, 225-236.

Ollinger, S.V., Smith, M.L., Martin, M.E., Hallett, R.A., Goodale, C.L., Aber, J.D., 2002. Regional variation in foliar chemistry and $\mathrm{N}$ cycling among forests of diverse history and composition. Ecology 83, 339-355.

Pennock, D.J., Zebarth, B.J., de Jone, E., 1987. Landform classification and soil distribution in hummocky terrain Saskatchewan, Canada. Geoderma 40, 297-315.

SAS Institute, 1990. SAS/STAT User's Guide, Version 6, 4th edition. SAS Institute, Cary, NC.

Schaetzl, R.J., 1990. Effects of tree throw microtopography on the characteristics and genesis of Spodosol, Michigan, USA. Catena $17,111-126$.

Soil Survey Laboratory Staff, 1996. Soil Survey Laboratory Methods Manual. Soil Survey Investigations Report, vol. 42. National Soil Survey Center, Lincoln, NE Version 3.0. USDA-NRCS.

Soil Survey Staff, 1999. Soil Taxonomy: A Basic System of Soil Classification for Making and Interpreting Soil Surveys. USDANRCS, 2nd ed. Agricultural Handbook, vol. 436. U. S. Gov. Print. Office, Washington, DC.

Stolt, M.H., Baker, J.C., Simpson, T.W., 1993. Soil-landscape relationships in Virginia: II. Reconstruction analysis and soil genesis. Soil Sci. Soc. Am. J. 57, 422-428.

Sugden, A.M., 1985. Leaf anatomy in a Venezuelan montane forest. Bot. J. Linn. Soc. 90, 231-241.

Sun, I.F., Hsieh, C.F., Hubbell, S.P., 1998. The structure and species composition of a subtropical monsoon forest in southern Taiwan on a steep wind-stress gradient. In: Dallmeier, F., Comiskey, J.A. (Eds.), Forest Diversity Research, Monitoring and Modeling: Conceptual Background and Old World Case Studies. Parthenon Publishing, Paris, pp. 565-635.

ter Braak, C.J.F., 1990. CANOCO-A FORTRAN program for canonical community ordination by [partial] [detrended] [canoni- 
cal] correspondence analysis, principal components analysis and redundancy analysis (version 3.10). Agricultural mathematics Group, Wageningen.

Van Breemen, N., Finzi, A.C., 1998. Plant-soil interactions: ecological aspects and evolutionary implications. Biogeochemistry $42,1-19$.

Van Breemen, N., Finzi, A.C., Canham, C.D., 1997. Canopy tree- soil interactions within temperate forests: effects of soil elemental composition and texture on species distributions. Can. J. For. Res. 27, 1110-1116.

Venterea, R.T., Lovett, G.M., Groffman, P.M., Schwarz, P.A., 2003. Landscape patterns of net nitrification in a northern hardwoodconifer forest. Soil Sci. Soc. Am. J. 67, 527-539. 